
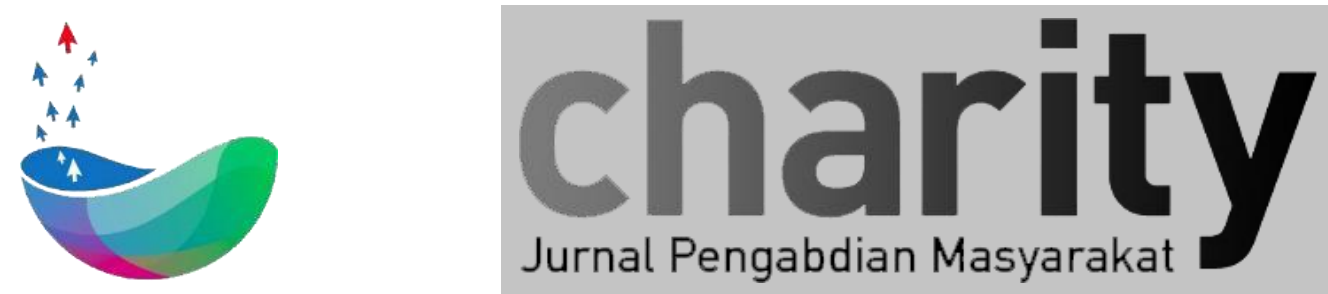

\title{
Implementasi Kurikulum Robotik di Madrasah Tsanawiyah Pondok Pesantren Husnul Khotimah 2 Kuningan
}

\author{
Ari Yanuar Ridwan ${ }^{1}$, M. Fahrul Rizal ${ }^{2}$, M. Deni Akbar ${ }^{3}$, Yahdi Siradj ${ }^{4}$, Agus Kusnayat \\ Program Studi S1 Teknik Industri, Fakultas Rekayasa Industri, Universitas Telkom \\ Program Studi D4 Multimedia, Fakultas Ilmu Terapan, Universitas Telkom \\ Program Studi S1 Teknik Industri, Fakultas Rekayasa Industri, Universitas Telkom \\ ${ }^{4}$ Program Studi D4 Multimedia, Fakultas Ilmu Terapan, Universitas Telkom \\ Program Studi S1 Teknik Industri, Fakultas Rekayasa Industri, Universitas Telkom \\ * ariyanaur@telkomuniversity.ac.id, denimath@telkomuniversity.ac.id
}

\section{INFO ARTIKEL}

Diterima 07 Februari 2020

Direvisi 13 Juli 2020

Disetujui 27 Agustus 2020

Tersedia Online 28 Agustus 2020

Keyword: Robotik; kurikulum; Pesantren; Industri 4.0

\begin{abstract}
ABSTRAK
Kemampuan yang harus disiapkan dalam menghadapi era Industri 4.0 diataranya adalah kemampuan terkait Teknologi Informasi, robotika, dan otomasi. Kemenristek Dikti sudah mencanangkan bahwa kurikulum pendidikan harus sesuai dengan kebutuhan industri 4.0. Pondok Pesantren Husnul Khotimah 2 (PPHK) Kuningan Jawa Barat adalah salah satu Pondok Pesantren Unggulan di Jawa Barat. PPHK 2 sudah mendapatkan A dan memiliki prestasi menjadi juara kompetisi di Tingkat Nasional baik dalam bidang sains maupun Musabaqah Quran. Saat ini kurikulum pendidikan di PPHK 2 maupun kegiatan ekstra kurikuler belum mendukung ke arah kompetensi RI 4.0. Sehingga perlu dibantu untuk dirancang kurikulum yang sesuai dengan kebutuhan tersebut. Tujuan Pengabdian Kepada Masyarakat ini adalah untuk merancang dan implementasi kurikulum Robotik yang disesuaikan dengan kebutuhan kurikulum sekolah di tingkat Madrasah Tsanawiyah PPHK 2. Pengenalan robotik ini menjadi penting dalam mempersiapkan siswa menghadapi era revolusi industri 4.0 (IR 4.0). Secara umum solusi dan tahapan aktivitas pengabdian terbagi ke dalam tiga tahap,yaitu: (1) Mengembangkan kurikulum robotik; (2) Pelatihan implementasi kurikulum robotik; (3) Pembentukan kelompok ilmiah remaja (KIR) Robotik. Output yang diharapkan dari pengabidian kepada masyarakat ini adalah: (1) Adanya kurikulum robotik di MTS PPHK 2; (2) Adanya Guru-Guru yang bisa menghantarkan kurikulum robotik kepada Siswa sesuai dengan kurikulum yang sudah dirancang; (3) Adanya Kelompok Ilmiah Remaja (KIR) untuk memperdalam pengetahuan robotik. Sehingga pada akhirnya ada outcome yaitu: (1) Peningkatan prestasi Siswa dalam kejuaran robotik tingkat daerah; (2) Meningkatkan citra pesantren Husnul Khotimah sebagai pesantren berbasis akhlak dan ilmu pengetahuan; (3) Meningkatkan minat siswa pesantren kepada ilmu robotik. Evaluasi Pelaksanaan dilakukan dengan cara: (1) Penyebaran kuisioner untuk mengukur pencapaian output/outcome dari hasil implementasi kurikulum; (2) kunjungan dan observasi lapangan; (3) pendampingan.
\end{abstract}

Korespondensi:

Direktorat Penelitian dan Pengabdian Masyarakat, Universitas Telkom

Jl. Telekomunikasi No. 1, Terusan Buah Batu, Bandung, 40257

Indonesia

E-mail : ppm@telkomuniversity.ac.id 


\section{Pendahuluan}

Pondok Pesantren Husnul Khotimah yang telah berdiri sejak tahun 1994, di atas lahan 6 (enam hektar) dan berlokasi di desa maniskidul Kecamatan Jalaksana Kab. Kuningan Jawa Barat ini, berupaya memenuhi harapan dan kebutuhan tersebut dengan mengedepankan pola Tarbiyah Islamiyah yang modern, Sistematis dan terpadu, namun tanpa meninggalkan pola Salafiyah.

Pesantren memiliki peran krusial dalam mempersiapkan generasi dan pemimpin masa depan Bangsa (Gazali, 2018). Hal ini dibuktikan juga lewat sejarah kehidupan berbangsa dan bernegara dimana banyak pemimpin bangsa lahir dari pesantren. Disamping aspek pendidikan dan penguatan sumber daya manusia, pesantren juga memiliki persan penting dalalm kehidupan sosial dan ekonomi masyarakat (Gazali, 2018). Hal ini terlihat dimana ada pesantren umumnya kehidupuan sosial dan ekonomi masyarakat ikut berkembang. Revolusi Industri 4.0 membawa dampak kepada semua bidang termasuk ke dalam pendidikan pesantren (Gazali, 2018). Era revolusi industri 4.0 (RI 4.0) membawa dampak yang bersar termasuk ke dalam pendidikan madrasah dan pesantren (Priatmoko, 2018). Hal ini disebabkan karena disamping kekhasan pesantren dalam menjalankan pendidikan berbasis agama namun pesatren juga harus mempersiapkan lulusannya untuk bisa beradaptasi dengan perkembangan zaman dan lingkungan ke depan. Pesantren harus mengembangkan kurikulumnya yang sesuai dengan kebutuhan RI 4.0 ini. Pendidikan pesantren dikhawatirkan akan menghasilkan lulusan yang tidak mampu berkompetisis dan berkontribusi maksimal ketika kurikulum yang ada belum menyesuaikan dengan kebutuhan RI 4.0. Kurikulum Pesantren umumnya belum menyesuaikan dengan kebutuhan Industri 4.0 yang diantaranya ditandai dengan belum masukknya konten kurikulum yang memuat tentang pengetahuan kecerdasan buatan, otomasi, robotik, dan cyber phycisal system.

Kehadiran revolusi industri 4.0 memang menghadirkan lini usaha baru, lapangan kerja baru, profesi baru yang tak terpikirkan sebelumnya. Namun pada saat yang sama ada pula lini usaha yang terancam, profesi dan lapangan kerja yang tergantikan oleh mesin kecerdasan buatan dan robot (Ghufron, 2018). Sejumlah penelitian termasuk yang dilakukan oleh McKinsey (2016) meprediksi bahwa terjadi perubahan pola kerja dan jenis pekerjaan yang diperkiraan hingga mencapai 52,6 juta lapangan pekerjaan akan tergantikan dalam lima tahun ke depan. Salah satunya oleh adanya perkembangan teknologi otomasi dan robotik. Sehingga siswa harus dipersiapkan dengan skill yang sesuai dengan kebutuhan lapangan pekerjaan tersebut yaitu diantaranya adalah kemampuan terkait teknologi otomasi dan robotik (Prasetyo \& Sutopo, 2018). Guru-guru harus mampu untuk mengajarkan konten tersebut disertai dengan kemampuan untuk beradaptasi dengan gaya pembejaran millenial. Guru Pesantren belum dibekali kemampuan untuk menyampaikan kontek tentang kurikulum Revolusi Industri 4.0. disamping itu kemampun untuk menyampaikan kontek yang sesuai dengan tipikal generasi milenial 
Dalam menghadapi era RI 4.0 disamping harus memperkuat karakter juga harus meningkatkan skill yang sesuai dengan kebutuhan RI 4.0 (Iswan \& Herwina, 2018). Kesiapan secara mental dan karakter untuk bisa beradaptasi dengan perkembangan teknologi yang cepat. Kemampuan untuk belajar cepat dan bekerja dalam lingkungan kolaborasi didukung oleh teknologi informasi. Salah satu karakteristik unik dari industri 4.0 adalah pengaplikasian kecerdasan buatan atau artificial intelligence (Tjandrawinata, 2016). Salah satu bentuk pengaplikasian tersebut adalah penggunaan robot untuk menggantikan tenaga manusia sehingga lebih murah, efektif, dan efisien (Ghufron, 2018). Sehingga skill dalam mengelola teknologi robot ini menjadi salah satu skill yang harus dipersiapkan dalam menghadapi era RI 4.0. untuk bisa beradaptasi dengan kebutuhan tersebut, perlu dipersiapakan infrastruktur yang sesuai dan mendukung terutama dalam meningkatkan pengetahuan dan keterampilan pengaplikasian keceerdasan buatan, robotik, dan otomasi. Saat ini Pesantren dinilai belum memilliki infrastruktur yang memadai untuk menjalankan kurikulum 4.0. dimana kurikulum ini membutuhkan terutama infrastruktur teknologi diantaranya adalah teknologi robot, otomasi dan kecerdasan buatan.

Kemenristek Dikti (2018) mewajibkan untuk semua institusi pendidikan supaya mengembangkan kurikulum yang sesuai dengan era RI 4.0. Sekaligus mendorong untuk melakukan diseminasi dan pengabdian yang mendukung ke arah peningkatan kesiapan institusi pendidikan dalam menghadapi RI 4.0

Analisis permasalah yang dihadapi oleh Madrasah Tsnawiyah Ar-Ruhama ditampilkan dalam bentuk tabel weakness (kelemahan internal) dan threats (ancaman ekseternal) pada tabel 1.

Tabel 1. weakness (kelemahan internal) dan threats (ancaman ekseternal) MTs Husnul Khotimah 2 Kuningan

\begin{tabular}{|l|l|}
\hline Weaknesses (Kelemahan) & Threats (Ancaman) \\
- Pengajar belum mengenal tentang robotik & $\begin{array}{l}\text { - Siswa di negara lain sudah terbiasa dengan } \\
\text { robotik } \\
\text { dan otomasi } \\
\text { - Pengajar belum mengenal tentang } \\
\text { revolusi industri 4.0 dan urgensinya } \\
\text { dalam kurikulum } \\
\text { di masa depan otomasi menjadi kebutuhan } \\
\text { - Belum ada sarana dan prasarana untuk } \\
\text { mendukung kurikulum berbasis robotik } \\
\text { - Memungkinkan anak Indonesia kalah } \\
\text { bersaing di masa depan khususnya terkait } \\
\text { dan urgensinya untuk memenangkan } \\
\text { persaingan bangsa ke depan }\end{array}$ \\
\hline
\end{tabular}


Tabel 2. strength (kekuatan) dan opportunities (peluang) yang dimiliki Madrasah Tsnawiyah Ar-Ruhama

\begin{tabular}{|c|c|}
\hline $\begin{array}{l}\text { Strengths (Kekuatan) } \\
\text { - Akreditasi sekolah A } \\
\text { - } \text { Salah satu sekolah tingkat } \\
\text { menengah dan atas terbaik di } \\
\text { Kuningan } \\
\text { Juara Umum Olimpiade IPA tingkat } \\
\text { Kabupaten Kuningan empat kali } \\
\text { berturut-turut 2015-2018. } \\
\text { Juaran Olimpiade Sains Madrasah } \\
\text { Tingkat Nasional } \\
\text { Disamping prestasi sains (IPA dan } \\
\text { matematika) juga berprestasi secara } \\
\text { diniyah, diantarnya sekitar 50 santri } \\
\text { hafal al quran } 30 \text { juz setiap tahunnya } \\
\text { Memiliki sekitar 4000 santri dari } \\
\text { seluruh Indonesia (Aceh hingga } \\
\text { Papua) dan beberapa ada dari luar } \\
\text { negeri. } \\
\text { Alumninya banyak diterima di } \\
\text { Perguruan Tinggi terbaik baik } \\
\text { negeri maupaun swasta seperti UI, } \\
\text { ITB, IPB dan juga Universitas } \\
\text { Telkom } \\
\text { Memiliki guru-gurunya berkualitas } \\
\text { merupakan lulusan dari dalam dan } \\
\text { luar negeri, termasuk dari UI, ITB, } \\
\text { IPB, dll. } \\
\text { Mengintegrasikan pengajaran sains, } \\
\text { sosial, dan pesantren modern. } \\
\text { Menjadi salah satu sekolah } \\
\text { percontohan untuk implementasi } \\
\text { UNBK di Kuningan baik untuk } \\
\text { tingkat SMP maupun SMA. }\end{array}$ & $\begin{array}{l}\text { Opportunities (Peluang) } \\
\text { - Adanya peluang peningkatan } \\
\text { kualitas pengajaran dengan } \\
\text { memasukkan robotik ke dalam } \\
\text { kurikulum } \\
\text { - Adanya peluang untuk mendirikan } \\
\text { Kelompok Ilmiah Remaja (KIR) } \\
\text { Robotik di Lingkungan Pesantren } \\
\text { Husnul Khotimah. } \\
\text { Adanya peluang bantuan dari } \\
\text { Perguruan Tinggi dalam bentuk } \\
\text { pelatihan, pendampingan, } \\
\text { pengembangan sistem, sarana dan } \\
\text { prasaranan pendidikan } \\
\text { Adanya peluang bantuan dari } \\
\text { pemerintah dalam bentuk pelatihan, } \\
\text { pendampingan, pengembangan } \\
\text { sistem, sarana dan prasaranan } \\
\text { pendidikan pan dara } \\
\text { Adanya peluang bantuan dari } \\
\text { Perguruan Tinggi dalam bentuk } \\
\text { pelatihan, pendampingan, } \\
\text { pengembangan sistem, sarana dan } \\
\text { prasarana pendidikan } \\
\text { Adanya peluang bantuan dari } \\
\text { masyarakat dalam bentuk pelatihan, } \\
\text { pendampingan, pengembangan } \\
\text { sistem, sarana dan prasaranan } \\
\text { pendidikan }\end{array}$ \\
\hline
\end{tabular}

\section{Solusi Pengabdian Yang Ditawarkan}

Dari analisis situasi di atas, secara umum persoalan yang saat ini dihadapi oleh Pondok Pesatren Husnul Khotimah 2 (PPHK) dalam menghadapi Industri 4.0 (RI 4.0), adalah:

1. Permasalah kurikulum

Kurikulum Pesantren belum menyesuaikan dengan kebutuhan Industri 4.0 yang diantaranya ditandai dengan belum masukknya konten kurikulum yang memuat tentang pengetahuan kecerdasan buatan, otomasi, robotik, dan cyber phycisal system.

1. Permasalah Skill pengajar

Guru Pesantren belum dibekali kemampuan untuk menyampaikan kontek tentang kurikulum Revolusi Industri 4.0. disamping itu kemampun untuk menyampaikan kontek yang sesuai dengan tipikal generasi milenial.

2. Permasalahan infrastruktur teknologi 
Pesantren belum memilliki infrastruktur yang memadai untuk menjalankan kurikulum 4.0. dimana kurikulum ini membutuhkan terutama infrastruktur teknologi diantaranya adalah teknologi robot, otomasi dan kecerdasan buatan.

3. Permasalahan mental dan karakter

Kesiapan secara mental dan karakter untuk bisa beradaptasi dengan perkembangan teknologi yang cepat. Kemampuan untuk belajar cepat dan bekerja dalam lingkungan kolaborasi didukung oleh teknologi informasi.

Program priotasi yang akan dikembangkan adalah bidang masalah terkait kurikulum dan skill staff pengajar. Hal ini dikarenakan terkait infrastruktur membutuhakn biaya yang besar sedangkan permasalah mental dan karakter siswa akan dikelola oleh para Guru.

Tabel 3. Bidang masalah dan solusi permasalahan

\begin{tabular}{|l|l|l|}
\hline Bidang Masalah Mitra & Solusi permasalahan & Skala prioritas \\
\hline Kurikulum & $\begin{array}{l}\text { Pengembangan kurikulum } \\
\text { Robotik }\end{array}$ & Prioritas lewat PKM \\
\hline Skill Pengajar & $\begin{array}{l}\text { Peningkatan kapasitas } \\
\text { pengajar }\end{array}$ & Prioritas lewat PKM \\
\hline Infrastruktur & Pengembangan infrasturktur & $\begin{array}{l}\text { Membutuhkan biaya } \\
\text { besar }\end{array}$ \\
\hline Mental dan Karakter & $\begin{array}{l}\text { Pembinaan mental dan } \\
\text { karekter }\end{array}$ & Dikelola oleh Guru \\
\hline
\end{tabular}

Solusi yang ditawarkan adalah menggabungkan S-O Strategi (strategi yang disusun dengan cara menggunakan semua kekuatan untuk merebut peluang) dan W-O Strategi (strategi yang disusun dengan cara meminimalkan kelemahan untuk memanfaatkan peluang yang ada) yaitu sebagai berikut:

\begin{tabular}{|l|l|}
\hline $\begin{array}{l}\text { S-O Strategi } \\
\begin{array}{l}\text { Pengembangan Kurikulum Robotik Untuk } \\
\text { Mempersiapkan Siswa Menghadapai } \\
\text { Revolusi Industri 4.0 }\end{array}\end{array}$ & $\begin{array}{l}\text { W-O Strategi } \\
\text { Pengembangan sarana dan prasarana } \\
\text { pendukung kurikulum Robotik }\end{array}$ \\
\hline \multicolumn{2}{|}{$\begin{array}{c}\text { Solusi pengabdian yang ditawarkan: } \\
\text { Implementasi Kurikulum Robotik Untuk Mempersiapkan Siswa Menghadapai } \\
\text { Revolusi Industri 4.0 di Madrasah Tsanawiyah Pondok Pesantren Husnul Khotimah } \\
\text { 2 Kuningan }\end{array}$} \\
\hline
\end{tabular}

\section{Metode Pelaksanaan Kegiatan}

Bentuk kegiatan dari Program Pengabdian Masyarakat ini akan dilakukan secara bertahap, sesuai dengan target pekerjaan dari masing-masing Tim PkM. 

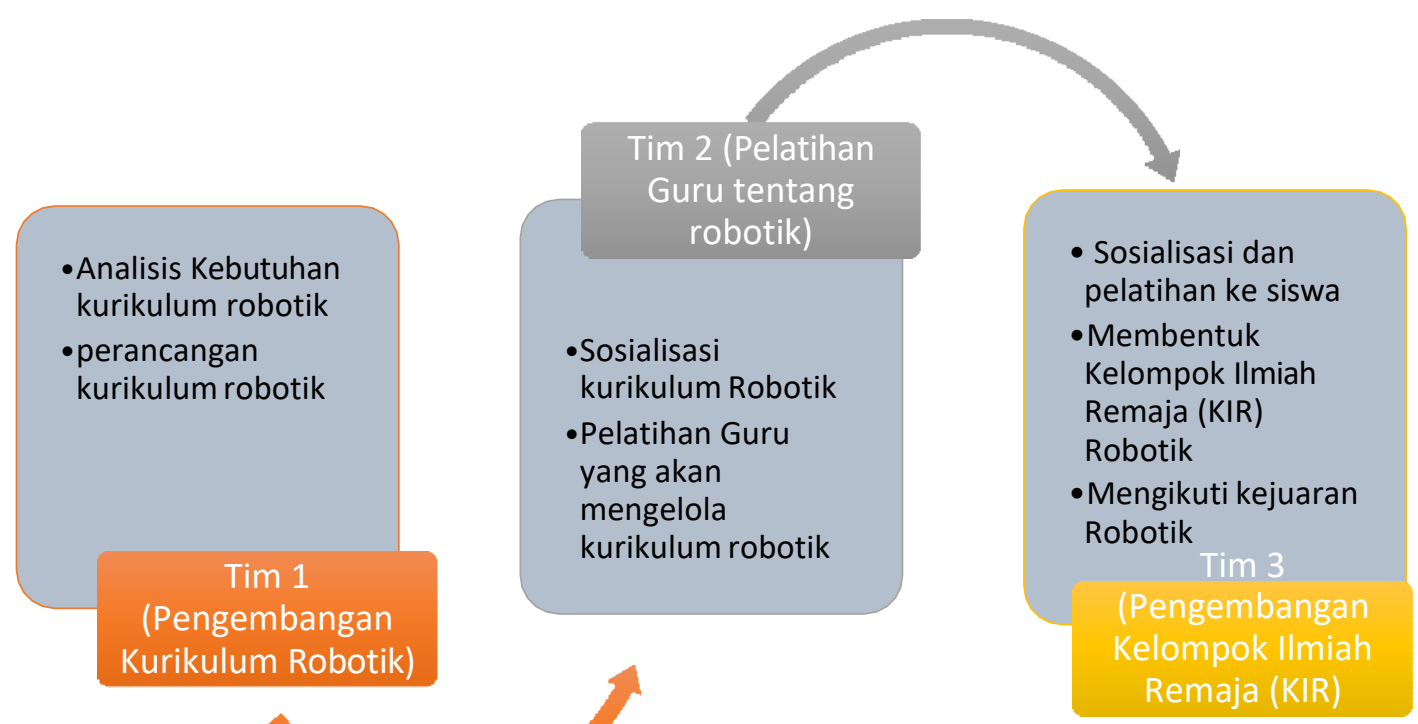

Gambar 1. Tahapan Kegiatan PkM Kolaborasi yang direncanakan

Pembagian Tugas dan Kegiatan setiap TIM, adalah sebagai berikut:

1. Tim 1 (Pengembangan Kurikulum Robotik)

- Analisis Kebutuhan kurikulum robotik

- perancangan kurikulum robotik

2. Tim 2 (Pelatihan Guru tentang robotik)

- Sosialisasi kurikulum Robotik

- Pelatihan Guru yang akan mengelola kurikulum robotik

3. Tim 3 (Pengembangan Kelompok Ilmiah Remaja (KIR) Robotik)

- Sosialisasi dan pelatihan ke siswa

- Membentuk Kelompok Ilmiah Remaja (KIR) Robotik

- Mengikuti kejuaran Robotik

\section{Partisipasi Mitra Dalam Pelaksanaan Program}

kegiatan Pengabdian Kepada Masyarakat ini akan bekerja secara bertahap terdasarkan pembagian tugas dalam tiga tim di atas. Pondok pesantren husnul Khotimah sebagai mitra, dilibatkan dalam setiap tahapan kegiatan untuk bisa mendapatkan hasil sesuai yang dibutuhkan oleh mitra.

Berikut ini partisipasi yang dilakukan oleh pihak mitra Pondok Pesantren Husnul Khotimah sesui dengan aktivitas yang dilakukan oleh setiap tim:

1. Tim 1 (Pengembangan Kurikulum Robotik)

- Mitra membantu untuk menyiapkan data Analisis Kebutuhan kurikulum robotik

- Mitra membantu untuk menyiapkan perancangan kurikulum robotik

2. Tim 2 (Pelatihan Guru tentang robotik)

- Mitra membantu untuk Sosialisasi kurikulum Robotik

- Mitra membantu untuk Pelatihan Guru yang akan mengelola kurikulum robotik

3. Tim 3 (Pengembangan Kelompok Ilmiah Remaja (KIR) Robotik)

- Mitra membantu untuk sosialisasi dan pelatihan ke siswa

- Mitra membantu untuk membentuk Kelompok Ilmiah Remaja (KIR)Robotik

- Mitra membantu untuk medorong Siswa mengikuti kejuaran Robotik 


\section{Keberlanjutan Program}

Kurikulum robotik ini selanjutnya akan digunakan dan dikembangkan di lingkungan Pondok Pesantren Husnul Khotimah dalam menunjang proses pembelajaran mempersiapkan siswa menghadapi era revolusi industri 4.0. Guru akan membimbing siswa dalam Kelompok Ilmiah Remaja (KIR) Robotik . Tim dari KIR Robotik akan dikirim untuk mengikuti kejuaran Robotik tingkat lokal dan nasional. Tim dari Universitas Telkom akan terus memonitor dan melakukan evaluasi implementasi kurikulum robotik ini karena sesuai dengan roadmap pengabdian pada tahap selanjutnya akan coba untuk diimplementasikan melibatkan lebih dari satu sekolah sehingga terjadi suatu kolaborasi.

\section{Photo-Photo Kegiatan}
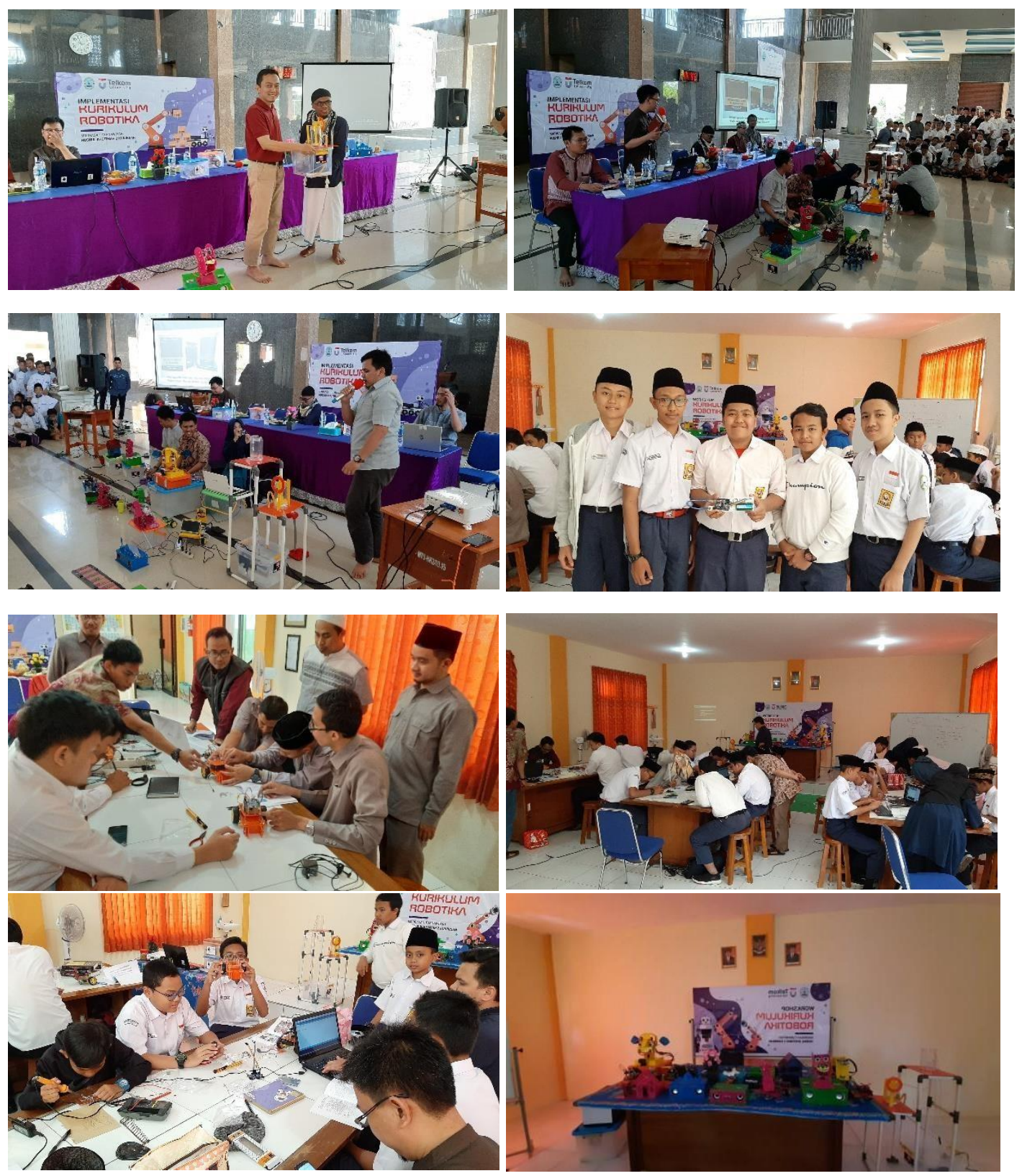

Gambar 2. Kegiatan Pengabdian Masyarakat 


\section{DAFTAR PUSTAKA}

1. Priatmoko, S. (2018). Memperkuat Eksistensi Pendidikan Islam di Era 4.0. Jurnal Studi Pendidikan Islam, Vol. 1, No.2, Edisi Juli

2. Tjandrawina, R.R. (2016). Industri 4.0: Revolusi industry abad ini dan pengaruhnya pada bidang kesehatan dan bioteknologi. Jurnal Medicinus, Vol 29, Nomor 1, Edisi April

3. Gazali, E. (2018). Pensantren Diantara Generasi Alfa dan Tantangan Dunia Pendidikan Era Revolusi Industri 4.0. OASIS: Jurnal Ilmiah Kajian Islam, Vol. 2, No. 2, Edisi Februari

4. Iswan, Herwina. (2018). Penguatan Karakter Perspektif Islam dalam Era Millenial 4.0. Prosiding Nasional Pendidikan Universitas Muhammadiyah Jakarta

5. Ghufron, M.A. (2018). Revolusi Industri 4.0: Tantangan, Peluan, dan Solusi bagi Dunia Pendidikan. Seminar Nasional dan Diskusi Panel Multidisiplin Hasil Penelitian dan Pengabdian, Agustus.

6. Prasetyo, H., Sutopo, W. (2017). Perkembangan Keilmuan Tenik Industri Menuju Era Industri 4.0. Seminar dan Konferensi Nasional IDEC.

7. Kemenristek Dikti. (2018). https://ristekdikti.go.id/kabar/menristekdikti-perlureorientasi-kurikulum-untuk-meningkatkan-inovasi-perguruan-tinggi-di-era-revolusiindustri-4-0/. Diakes 30 Oktober 2018 